\title{
INVESTAVIMO STRATEGIJŲ PASIRINKIMO GALIMYBIŲ ANALIZE் IR JŲ KLASIFIKAVIMAS AKCIJŲ RINKOJE
}

\author{
Ieva GAIGALAITÉ ${ }^{1}$, Grigorij ŽILINSKIJ² \\ Vilniaus Gedimino techniko universitetas, Verslo vadybos fakultetas, \\ Finansu inžinerijos katedra, Saulètekio al. 11, LT-10223 Vilnius, Lietuva \\ El.paštas: ${ }^{1}$ ieva.gaigalaite@gmail.com; ${ }^{2}$ grigorij.zilinskij@vgtu.lt
}

\begin{abstract}
Santrauka. Straipsnyje yra nagrinėjamos investavimo akcijų rinkoje strategiju pasirinkimo galimybės, bei strategijos yra klasifikuojamos, pagal investuotojų elgseną rinkoje ir kaip aktyviai jie dalyvauja investavime. Išnagrinejjus literatūroje pateikiamas investavimo sąvokas ir pasiūlius jas apibendrinantị investavimo apibrèžimą, trumpai pristatoma investavimo strategijos sąvoka, išskiriamos pagrindinès dvi investavimo strategiju grupès. İvertinus literatūroje sutinkamų investavimo strategijų ịvairovę ir trumpai jas aprašius, informacija apie strategijas yra sisteminama, remiantis bendrais investuotoju aktyvumo bruožais ir pasiūlant galimą aktyvaus ir pasyvaus investavimo strategijų klasifikavimą. İvertinus aktyvaus ir pasyvaus investavimo strategijų ypatybes pateikiamos ¡žvalgos dèl investavimo priemoniu pasirinkimo aktyviai ir pasyviai investicijas valdantiems investuotojams, priklausomai nuo investuotojų požiūrio, lūkesčių ir aktyvumo.
\end{abstract}

Reikšminiai žodžiai: investavimas, investicijų valdymas, investicijų portfelis, investavimo strategija, aktyvus investavimas, pasyvus investavimas. E32.

\section{Ivadas}

Visuomenès poreikių neįmanoma patenkinti ir jie yra begaliniai, visuomenè ieško papildomų galimybių gauti antriniu pajamų, o investavimas, tai puiki galimybè padidinti savo finansinius aktyvus. Siuolaikinès finansų rinkos suteikia investuotojams vis daugiau galimybių panaudoti savo finansinius išteklius tikintis teigiamos grąžos. Dažniausiai investavimo sąvoka suprantama, kaip laisvo kapitalo panaudojimas, investuojant ir gaunant už investiciją grąžą. Kadangi daugèja galimybių privatiems investuotojams, kartu auga ir bendras visuomenès finansinis raštingumas ir vis labiau suprantama investavimo nauda. Investuotojai turèdami vis daugiau žinių, atidžiau renkasi finansinius aktyvus ir investavimo strategijas, kurios atrodo jiems patrauklesnès, bei labiau atitinka išsikeltus finansinius tikslus.

Suprantama, kad ne kiekvienas gali būti sèkmingas investuotojas, todèl norint pagerinti savo rezultatą, reikia nusistatyti tinkamus tikslus, apsispręsti kiek laiko bus galima skirti investavimui, bei išsigryninti investavimo strategiją, kuri yra būtina siekiant kaip įmanoma geresnio rezultato. Investavimo strategija yra vienas iš svarbiausių ir aktualiausių investavimo proceso dalių, nes be jo neimmanoma užtikrinti gerų investavimo rezultatu. Kadangi investavimas egzistuoja jau ilgus metus ir procesas yra plačiai išnagrinetas, todèl ir investavimo strategijos pasižymi didele gausa. Mokslinèje literatūroje strategijos yra nagrinèjamos plačiai ir aptinkama nemažai skirtingu požiūriụ, bei vertinimų. Dèl didelès gausos studijų išryškèja problema, kad neturinčiam daug patirties investuotojui yra sunku susigaudyti ir suprasti investavimo strategijas, nes dažniausiai mokslininkai pasirenka nagrinèti vieną konkrečią strategiją, o platesnès investavimo strategiju pasirinkimo galimybiu analizès nèra, bei apibendrintos informacijos apie jų įvairovę jaučiamas trūkumas.

Darbo tikslas - išanalizuoti investavimo strategijų pasirinkimo galimybes, susisteminti literatūroje pateikiamą medžiagą sudarant strategijų klasifikaciją, kuri leistų investuotojams lengviau pasirinkti jiems tinkamiausią investavimo strategiją.

Darbo tikslui pasiekti, iškelti tokie darbo uždaviniai:

- Išnagrinèti literatūroje pateikiamus investavimo sąvokos apibrěžimus bei pasiūlyti juos apibendrinanti apibrežimą.

- Išnagrinèti literatūroje pateiktų pasyvaus investavimo strategijų ịvairovę ir pasiūlyti jas apibendrinančią klasifikaciją.

- Išnagrinèti literatūroje pateiktų aktyvaus investavimo strategijų ịvairovę ir pasiūlyti jas apibendrinančią klasifikacija.

- Pateikti pasiūlymus dèl investavimo priemoniu pasirinkimo aktyviai ir pasyviai investicijas valdantiems investuotojams. 


\section{Investavimo sąvokos ir strategijos teorinè analizè}

Investavimo teoriniai aspektai

Lietuvos Respublikos investicijų ịstatyme (1999) investavimas apibrèžiamas, kaip šio ịstatymo nustatytais būdais atliekami investuotojo veiksmai, kuriais jis ịgyja nuosavybès teisę arba kreditoriaus reikalavimo teisę į investavimo objektą arba teisę šị objektą valdyti ir naudoti.

Taip pat reikètų apibrěžti investavimui aktualią investicijų sąvoką, kuri Lietuvos Respublikos investicijų įstatyme (1999) yra apibūdinama, kaip piniginès lèšos ir įstatymais bei kitais teisès aktais nustatyta tvarka ịvertintas materialusis, nematerialusis ir finansinis turtas, kuris investuojamas siekiant iš investavimo objekto gauti pelno (pajamų), socialinị rezultatą (švietimo, kultūros, mokslo, sveikatos ir socialinès apsaugos bei kitose panašiose srityse) arba užtikrinti valstybès funkcijų ịgyvendinimą. Treigienè (2010) investicijas apibūdina, kaip pinigines lèšas ir kitą finansinị turtą bei materialųji ir nematerialųji turtą, kuris yra investuojamas siekiant investavimo objekto gauti pelną arba kitą rezultatą. Informacija apie literatūros šaltiniuose rastus investavimo sąvokos apibrèžimus pateikta 1 lenteleje.

1 lentelè. Investavimo sąvoku palyginimas (sudaryta autoriu) Table 1. Investment conceptual comparison (developed by the authors)

\begin{tabular}{|c|c|}
\hline Autorius, metai & Apibrèžimas \\
\hline Kancerevyčius 2009 & Investavimas reiškia tikro dabartinio vartojimo atsisakymą dèl ateities vartojimo \\
\hline Jurevičienè 2008 & $\begin{array}{l}\text { Investavimas, tai pinigu ịdèjimas ị vertybinius popierius ar materialų turtą, siekiant } \\
\text { gauti vertès padidėjimo, pajamų ar abu dalykus. }\end{array}$ \\
\hline Černius 2011 & Investavimas, tai pinigu , „idarbinimas“ siekiant kuo didesnès naudos \\
\hline Valakevičius 2008 & $\begin{array}{l}\text { Investavimas, tai yra šiandieninės vertės (pinigų ar kitų kapitalinių išteklių) aukoji- } \\
\text { mas perkant realụji turtą ar vertybinius popierius, tikintis ateityje gauti didesnę } \\
\text { vertę, proporcingą prisiimtai rizikai }\end{array}$ \\
\hline Bodie, Kane, Marcus 2013 & $\begin{array}{l}\text { Investavimas yra dabartinis įsipareigojimas pinigais ar kitais ištekliais viliantis } \\
\text { patirti būsima naudą. }\end{array}$ \\
\hline Rutkauskas, Stankevičius 2006 & $\begin{array}{l}\text { Investavimas - tai kapitalo panaudojimo būdas, kuris privalo užtikrinti kapitalo } \\
\text { saugumą ir vertès augimą. }\end{array}$ \\
\hline Macijauskas 2015 & $\begin{array}{l}\text { Investavimas - tai mechanizmas, kuriuo asmenys, turintys tuo laikotarpiu laisvų } \\
\text { lěšų, gali suteikti galimybę jas panaudoti tiems, kuriems tuo metu trūksta lèšų. }\end{array}$ \\
\hline
\end{tabular}

Apibendrinant investavimo ir investicijų sąvokas galime daryti išvadą, kad investavimas, tai mechanizmas, kurio yra atsisakoma dabartinio vartojimo perkant vertybinius popierius ar kitą turtą ir tikintis finansinès grąžos, socialinio rezultato arba kitos naudos ateityje.

\section{Investavimo strategijos sąvokos apibrèžimas}

Investavimo strategija, tai tam tikros taisyklès, elgesio bruožai ar procedūros, kurios sukurtos tam kad investuotojas pasirinktų investicinio portfelio valdymo būdą. Strategija turi būti pasirenkama pagal investuotojo nustatytus tikslus bei poreikius, nes tai nulems ar strategija bus ilgalaike ar trumpalaike, investuotojo rizikos tolerancijos lygị. Strategiją reiktų suvokti, kaip strateginio investavimo tikslo (investicinès vertès maksimizavimo), remiantis strateginèmis priemonėmis (tinkamiausių investavimo šaltinių ir būdų pasirinkimu), atsižvelgus į strateginius apribojimus (laiko ir rizikos įtaką) bei strategines investavimo i pasirinktą turtą funkcijas (atidèto vartojimo maksimizavimą), pasiekimą (Rutkauskas, Martinkutè 2000). Strategija finansuose dažniausiai suprantama, kaip planas, kurio tikslas pasiekti didžiausią naudą. Investavimo strategija, tai investavimo sprendimai, kuriais investuotojas tikisi gauti didžiausią pelną ir patikimumą (Rutkauskas et al. 2008).

Martinkutès-Kaulienès (2006) teigimu, investavimo strategijai yra būdingi trys bruožai, tai požiūris 1) ị riziką, 2) investavimo laikotarpi 3) ateities poreikius. Investuotojui prieš pradedant išsirinkti investavimo strategiją reikia išsiaiškinti savo poreikius, ar jis sieks didesnès investicinès grąžos ar jo tikslas yra tik pasideti saugiai pinigus ir apsaugoti juos nuo infliacijos. Taip pat svarbu nuspręsti investuotojui kokiam laikui jis nori investuoti pinigus.

\section{Investavimo strategijos akciju rinkoje}

Daugelyje literatūros šaltinių galima rasti du tipus strategijų, tai aktyvaus ir pasyvaus valdymo strategijos. Taip pat kai kurie autoriai išskiria aktyvaus ir pasyvaus valdymo strategijų mišinį, tačiau tai yra tik aktyvios strategijos variacijos (Reilly, Brown 2006). Dierkes et al. (2010) skirsto investavimo strategijas ne ị aktyvias ir pasyvias, bet i paremtas prognozėmis ir neparemtas. Pagal turini strategijos, kurios nėra paremtos prognozėmis dažniausiai naudojamos pasyviai valdant investicijų portfelį, o aktyvus valdymas dažniausiai yra paremtas prognozėmis. Neparemtos prognozėmis strategijos taip pat gali būti skirstomos ị strategijas, kurios reikalauja perbalansavimo ir kurios 
to nereikalauja. Tai parodo, kad kadangi literatūroje galima rasti ịvairių strategijų, dalis jų negali būti vienareikšmiškai priskirtos vienai strategiju grupei. Atskiros strategijos gali tūrèti ne vien pasyvaus investavimo bruožų bet ir aktyvaus. Dèl šios priežasties tolimesnèje studijoje pateiktas klasifikavimas yra santykinis, neịvertinant, to kad kai kurios strategijos turi tiek aktyvaus, tiek pasyvaus valdymo elementų arba apjungia tiek prognozemis paremto, tiek prognozių neįvertinančio sprendimų prièmimo elementus, kaip pavaizduota 1 pav. Šiame paveiksle pavaizduota, kad tiek aktyvios, tiek pasyvios strategijos, bei prognozėmis paremtos ir neparemtos strategijos tarpusavyje persipina ir sunku yra nubréžti tikslią ribą tarp jų.
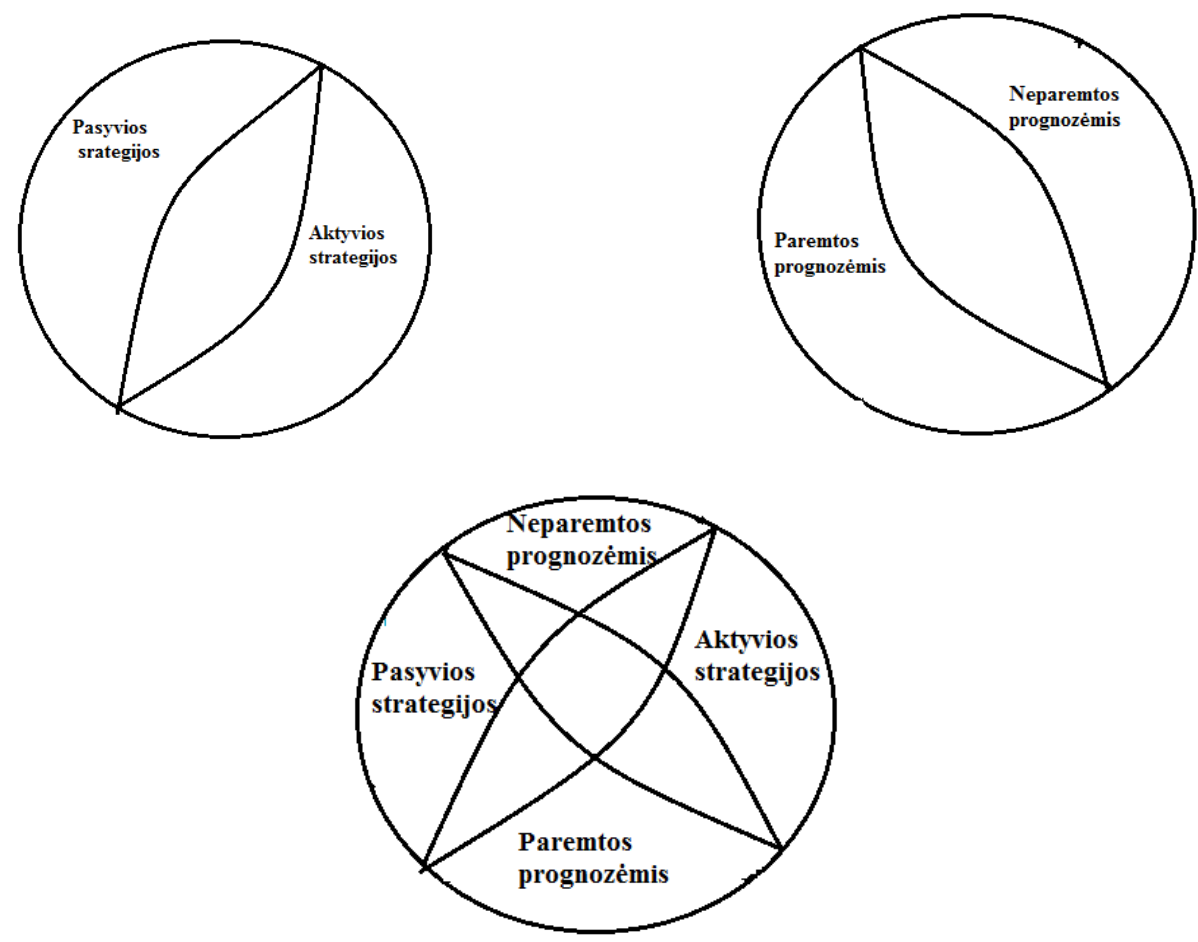

1 pav. Strategijų priskyrimas atskiroms strategijų grupėms (sudaryta autorių) Fig. 1. Strategies allocation strategies for individual groups (developed by the authors)

\section{Pasyvaus akciju portfelio valdymo strategija}

Pasyvaus investavimo strategijų tikslas yra maksimizuoti grąžą per ilgą laikotarpị. Kadangi ši strategija yra ilgalaikè, tai investuotojai nesitiki greitos finansinès naudos ar praturtejimo, tai daugiau strategija, kuri užtikrina lètą, pastovią grąžą. Taip pat pasyvūs investuotojai tiki efektyvios rinkos hipoteze. Reilly, Brown (2006) išskiria šiuos pagrindinius pliusus investuoti remiantis pasyvia strategija: akcijų rinka dažniausiai būna pakankamai efektyvi; daugeliui aktyvių investuotojų yra sunku pralenkti portfelio mokesčius ir gauti pelną.

Taip pat literatūroje yra išskiriamos dviejų tipų pasyvaus valdymo strategijos, tai:

- Pirk ir laikyk, tai ịsigytų investicijų išlaikymas per visą investavimą. Ši strategija paprastai investuotojų yra vertinama neigiamai, nes ji nesuteikia galimybès uždirbti daugiau nei rinka. Mcallen (2010) teigia, kad ši strategija niekada gerai neveikè ir neveiks.

- Indeksavimo strategija, tai investavimo strategija, kurios tikslas yra kaip įmanoma tiksliau atkartoti kokio nors specialaus indekso kitimą, tačiau dèl pinigu judejjimų, bankrotų ir ịmonių susiliejimų, vertybiniai popieriai turi būti nupirkti ir parduoti, dèl to nepavyksta visiškai tiksliai atkartoti indekso judejjimo ir išryškëja skirtumas bėgant laikui laikui (Reilly, Brown 2006)

Kanceravyčius (2006), Reilly, Brown (2006), bei Elton, Gruber (1995) išskiria tris pagrindines pasyvaus indekso portfelio sudarymo metodikas:

- Visiškas atkartojimas, tai yra paprasčiausias metodas, kai perkamos akcijos, kurios įeina i indeksą, ir tokiais kiekiais, kokia proporcija jos įeina ị indeksą. Taip yra gaunamas tiksliausias indekso sekimas, tačiau jis turi ir keletą minusų, tai perkant daug atskirų akcijų bus didelès sandorių sąnaudos, o dividendų reinvestavimai taip pat bus brangesni ir visa tai gerokai padidins atsilikimą nuo indekso pelningumo.

- Imties metodas, kai yra perkamos tik labiausiai indekso kaitą atspindinčios akcijos, tokiu būdu yra perkamas didesnis vienos įmonės akcijų skaičius, palyginus su pirmuoju būdu, dèl to reikia mažiau sumokèti komisinių, bei 
mažiau problemų sudaro dividendų reinvestavimas, tačiau portfelis nebe taip tiksliai atkartoja indekso kaitą. Reikia skaičiuoti, kas yra naudingiau - ar didesnè paklaida ir mažesni kaštai, ar tikslesnis sekimas ir didesni valdymo kaštai.

- Kvadratinis optimizavimas. Šiuo atveju portfeli parenka kompiuterio programa, atsižvelgdama ị istorinius koreliacinius tarp akcijų ir jų kainų pokyčių duomenis, siekiant minimizuoti sekimo paklaidą. Šio metodo trūkumas yra tai kad istoriniai duomenys nebūtinai atvaizduos ateitị ir gali būti labai didelis skirtumas nuo rinkos.

Dierkes et al. (2010) išskiria kelias pagrindines perbalansavimo strategijos, kurios nepaisant perbalansavimo savybès gali būti priskirtos pasyvaus investavimo strategijoms: pastovaus derinio, indeksavimo strategija, pastovaus derinio su draudimu strategija. Tačiau Zieling et al. (2014) papildomai prie pastovaus derinio portfelio su draudimu strategijos dar analizuoja ir pasirinkimu pagrịstą strategiją su draudimu.

Investavimas su draudimu suteikia galimybę investuotojui sumažinti riziką, bei dalyvauti augančioje rinkoje (Greqam, Thema 2004). Pastovaus derinio su draudimu strategija leidžia paprasčiau paskirstyti turtą besikeičiant laikui. Investuotojas pradeda nuo to, kad nustato priimtiną žemiausią vertę, o tada nustato galimą perviršị (Greqam, Thema 2004). Taip pat ši strategija labiausiai yra naudojama praktikų iš visų strategijų, kurios naudoja investavimą su draudimu ir garantuoja grąžą finansiniams produktams. Empiriniai tyrimai parodè, kad perbalansavimo taisyklès turi labai didelę įtaką šios strategijos rezultatams (Zhang et al. 2015). Pasirinkimu pagrịstos su draudimu strategijos pagrindinis tikslas yra garantuoti užtikrintą grąžą tam nustatytu metu, bei leidžia gauti portfelio draudimą, bet kuriuo metu (Greqam, Thema 2004).

Taip pat autorių nuomone prie šios strategijų grupès turètų būti priskirta indeksavimo strategija, nes reikalinga pergrupuoti portfelio sudètị, kai pasirinkto indekso reikšmei pradeda daryti daugiau ịtakos kitos ịmonès akcijos. Strategijoms, kurios nereikalauja perbalansavimo yra priskiriamos: pirk-laikyk strategija, grynosios akciju/obligacijų strategijos, bei mišrios, kurias sudaro 50 proc. akcijų ir 50 proc. obligacijų.

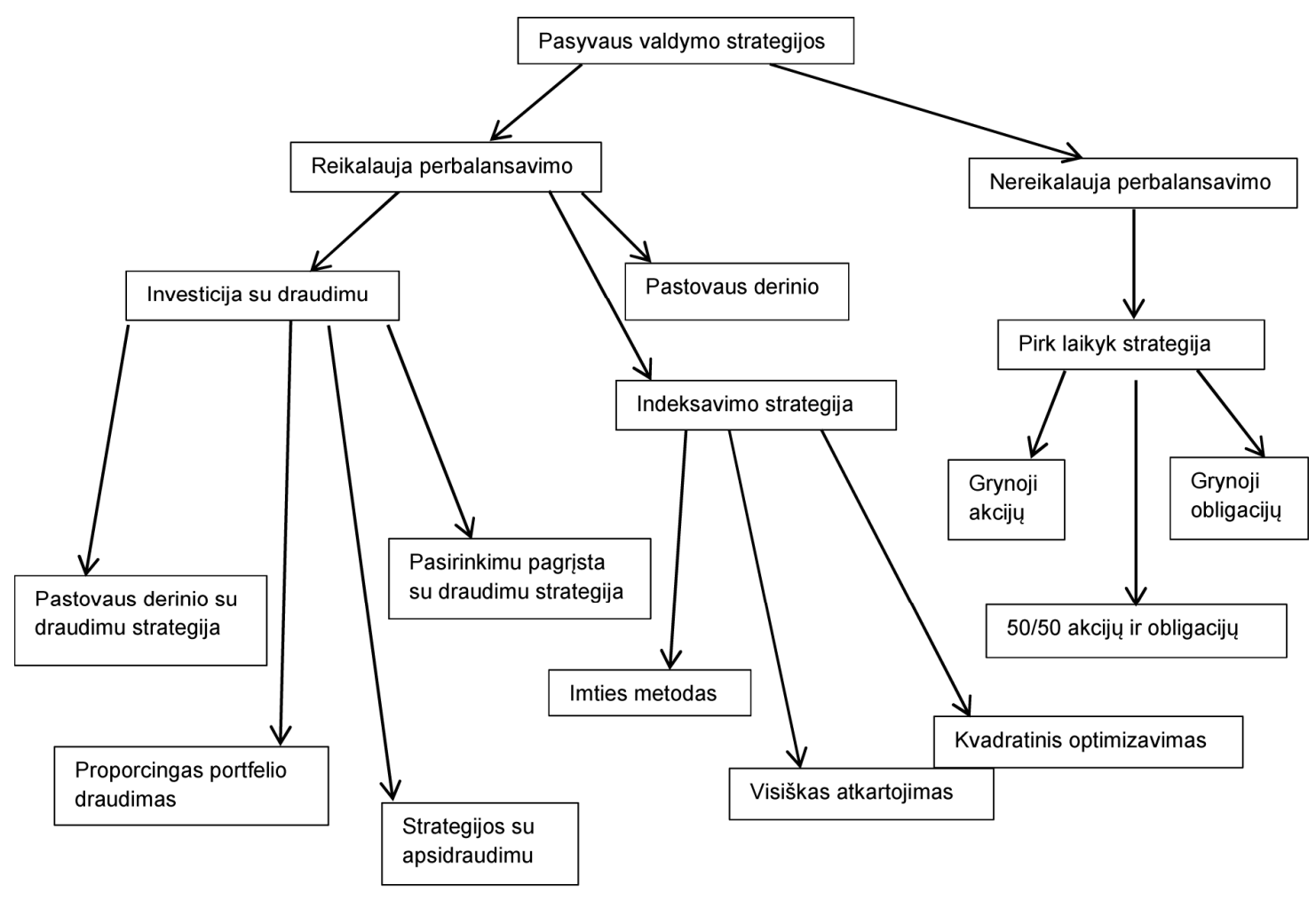

2 pav. Pasyvių strategijų klasifikavimas (sudaryta autorių remiantis Dierkes et al. 2010)

Fig. 2. Passive strategies classification (developed by the authors on the basis of Dierks et al. 2010)

Pasyvus investavimas yra ilgalaikis investavimas, nes tikima efektyvios rinkos teorija ir tuo, kad ilgalaikëje perspektyvoje vis tiek rinka sugeneruos teigiamą grąžą Reilly, Brown. (2006) išskiria šiuos pagrindinius investavimo taikant pasyvią strategiją privalumus: akcijų rinka dažniausiai būna pakankamai efektyvi; daugeliui aktyvių investuotojų yra sunku pralenkti portfelio mokesčius ir gauti pelną. 


\section{Aktyvaus akciju portfelio valdymo strategija}

Aktyvaus investavimo tikslas yra gauti geresnius negu pasyviojo portfelio rezultatus po sandorio sąnaudu (Kancerevyčius 2006). Taip pat investuotojas perkelia didesnę dalị investicijų ant vieno tipo akcijų, taip padidindamas portfelio riziką, todèl už prisiimamą didesnę riziką tikimasi didesnès grąžos. Aktyvios strategijos atveju portfelio valdytojas turi ịveikti didesnes sandorių sąnaudas, bei didesnę negu pasyvaus portfelio riziką. Investuotojas privalo per visą laikotarpi būti nuosaikiu ir laikytis savo investavimo filosofijos. Portfelio valdytojui svarbu įvertinti kiekvieną operaciją, nes jis taip padidina kaštus, kurie mažina pelną. Aktyvus investavimas pasižymi didesne rizika, bei didesniais mokesčiais.

Reilly, Brown (2006) išskyre aktyvias strategijas, kurios remiasi fundamentaliaja ir technine analizėmis. Fundamentaliajai analizei priskiriamas integruotas turto paskirstymas (integrated asset allocation), taktiné turto alokacija (tactical asset allocation), apdrausta turto alokacija (insured asset aalocation). Taktinè turto alokacija yra panaši i dinaminę ir strateginę turto alokaciją, tačiau tai yra aktyvi investavimo strategija, nes investuotojas gali laisvai keisti sektorius ar pagrindines turto klases, kuriuose mato didesni augimo potencialą. Investuojant remiantis apdrausta turto alokacija yra sukuriama pagrindinè turto bazè, kuri per laiką turètų nekisti. Kai portfelis pasiekia aukštesnę grąžą negu bazè, tada yra investuojama aktyviai ir stengiamasi kaip įmanoma pasiekti geresnių rezultatų. Jeigu tai atsitinka, kad investuojant gaunamas rezultatas yra mažesnis negu bazè, tada yra investuojamas ị nerizikingas finansines priemones ir laukiama kol grąža pasieks bazę. Kai yra investuojama remiantis integruota turto alokacijos strategija yra apsvarstomi tiek ekonominiai lūkesčiai, tiek rizikos tolerancija, o paskui sudaromas turto mišinys. Taktine turto alokacija ir apdrausta turto alokacija daugiau demesio skiria ị laukiamą grąžą, tačiau integruota turto alokacija ne visos apskaičiuoja rizikos tolerancijos lygi, bei realius pasikeitimus kapitalo rinkoje.

Reilly, Brown (2006) techninei analizei priskyre dvi strategijas, tai prieštaringa investavimo strategija (contrarian investment strategy) ir kainos impulso strategija (price momentum strategy). Prieštaringa investavimo strategija remiasi nuomone, kad geriausiai pirkti (parduoti), kai rinka yra mešku (bulių), tai yra geriausia pirkti tada kai kainos yra žemos, o parduoti, kai kainuos pasiekia aukštumas. Kainos impulso strategija remiasi nuomone, kad akciju kainos nekeičia savo krypties ir visada išlieka tokios pačios, todèl kylančios rinkos, išliks kylančiomis, o krentančios rinkos išliks krentančiomis. Haan, Kakes (2011) pažymi, kad užsienio investuotojai yra labiau linkę investuoti remiantis impulso strategija, o vietiniai - prieštaringa strategija. Taip pat autorius teigia, kad impulso strategija yra labiau rizikinga, tačiau didesne rizika atneša didesnị pelną. Yaqiong (2012) pastebi, kad šiose strategijose egzistuoja sausio sezoniškumas ir paprastai prieštaringa investavimo strategija sausio laikotarpiu yra pelninga, o impulso strategija turi tendenciją būti nuostolinga, todèl investuojant vidutiniam laikotarpiui reikia atkreipti dèmesị i impulso strategijos sezoniškumą. Rinkos laiko pasirinkimo strategija (angl., Market timing) -investuotojai atsižvelgdami i finansų rinkų būseną (rinkos fazes) perka arba parduoda vertybinius popierius; akcijų i̇sigijimas rinkai kylant, o pardavimas - leidžiantis (Wiedemer et al. 2012). Taip pat ši strategija savo turiniu yra labai panaši i kainos impulso strategiją, todè 2 pav. ji išvedama iš kainos impulso strategijos. Dichtl et al. (2016) ir kiti autoriai teigia, kad norint investuoti remiantis rinkos laiko pasirinkimo strategija yra reikalinga pakankamai tikslus prognozavimas, todèl ši strategija yra priskiriama prie techninès analizės. Tačiau nors yra reikalingas prognozavimas ši strategija yra pakankamai populiari tarp vidutiniškai arba mažai ịgudusių investuotojų. Kadangi tai yra aktyvi investavimo strategija ji reikalauja pastovaus rinkos sekimo ir stebejjimo. Taip pat šios strategijos panašumus galime ịžvelgti ị impulso strategiją, nes investuotojai remiantis šia strategija perka, kai yra žemos kainos, o parduoda, kai yra aukštos (bulių/meškų rinkos).

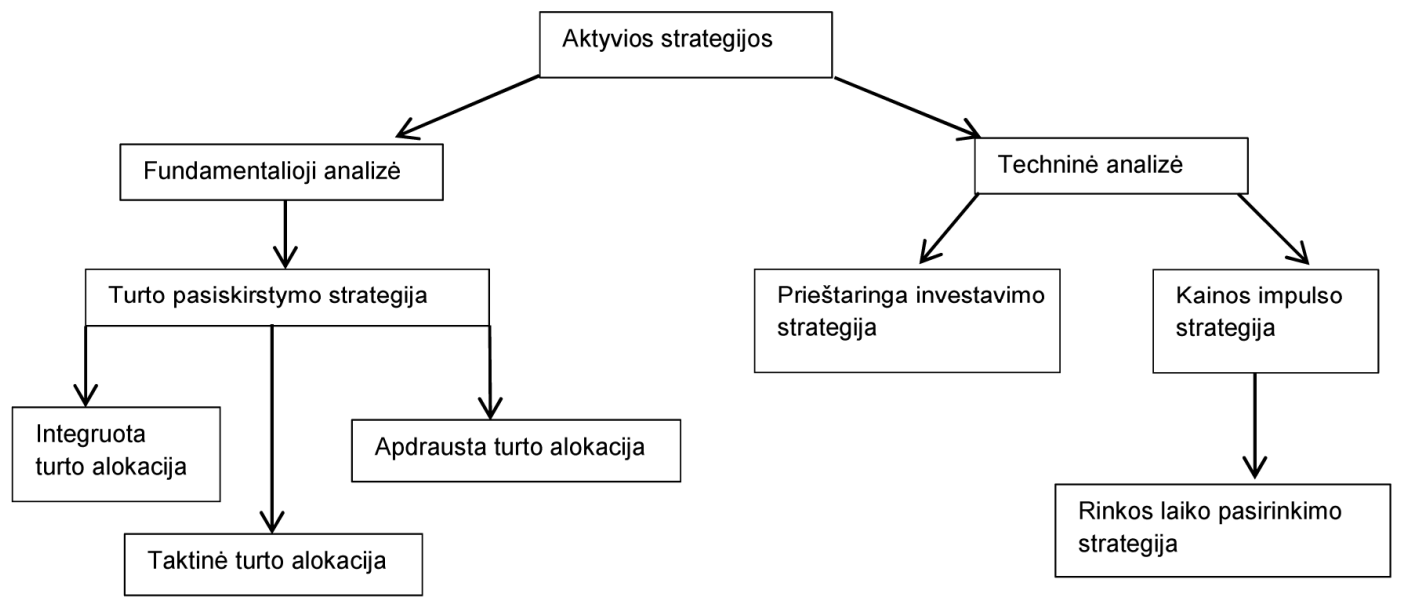

3 pav. Aktyvių strategijų klasifikavimas (sudaryta autorių remiantis Reilly, Brown (2006), Haan, Kakes. (2011))

Fig. 3. Classification of active strategies (developed by the authors on the basis of Reilly, Brown. (2006), Haan, Kakes (2011)) 
Aktyviems investuotojams dažnai tenka sekti ne vienos, o net kelių akcijų kainų pokyčius rinkoje, todèl gali būti pasirenkamos stop-loss (nuostolio ribojimo) ir lock in (pelno fiksavimo) strategijos, kurios gali būti naudojamos kartu su kainos impulso ir prieštaringo investavimo strategijomis. Stop - loss strategija yra palyginti paprasta, nes investuotojas investavęs tam tiktą sumą, nusistato kokius gali patirti nuostolius ir pasirinkęs tam tikrą sumą užsideda limitą ir tuo metu, kai investicijos verte krenta suveikia limitas ir investuotojas nepraranda daugiau pinigu negu nustatyta riba. Kung, Wu (2013) pažymi, kad stop - loss strategijos privalumas yra, tai kad investuotojui nereikia stebėti visą laiką investicijų, o trūkumas tai, kad nukristi kaina gali tik trumpam, o investicija bus parduota tuo momentu, kai tik kaina pasieks limitą. Taip pat tų pačių autorių yra išskiriama dar viena labai panaši strategija i stop - loss, tai Lock in strategija, kuri atvirkščiai, nei stop-loss nustato tikslinę grąžą, kuriai esant yra fiksuojamas pelnas.

Aktyvios investavimo strategijos yra skirtos investuotojams, kurie yra daugiau patyrę, bei turi daugiau žinių apie investavimą. Aktyvus investavimas reikalauja daugiau laiko resursų ir pastovaus rinkose sekimo.

\section{Finansinių aktyvų pasirinkimo galimybès}

Tiek investuojant aktyviai, tie pasyviai reikia apsispręsti, i kokios investavimo priemonės bus pasirenkamos. Aktyviai valdant investicijas, investuotojas uždirba pelną iš didelių kainų svyravimų santykinai trumpais laikotarpiais, t. y. investuojant net ị ilguoju laikotarpiu neperspektyvių įmonių akcijas galima uždirbti pelną. Tačiau konkrečios investavimo priemonès - įmonès akcijos - pasirinkimas pasyviam investuotojui yra labai svarbus. Literatūroje yra išskiriamos trys pagrindinės įmonių akcijų grupés, ị kurias tikslinga investuoti pasyvų investicijų valdymą pasirenkantiems investuotojams: vertès, augimo arba dividendinio pajamingumo įmonių akcijas.

Vertès investavimo principas yra toks, kad yra perkamos akcijos, kurios dẻl kažkokių priežasčių rinkoje yra nepakankamai ịvertintos ir pati rinka padare akcijos vertes klaidą. Vertès investavimo šalininkai teigia, kad rinka visada ištaiso savo padarytas klaidas ir todèl akcijos vertè laikui bėgant tūrètų pakilti. Remiantis šiuo požiūriu yra atliekama fundamentalioji analizė ir investuotojai daugiausia dèmesio atkreipia ị ịmones su stipriais finansiniai rodikliais: pajamų augimu, dividendais, pinigų srautais ir buhalterine įmonès verte (Lee et al. 2011). Daugiau dèmesio yra skiriama santykinių rodiklių analizei. Vertės investuotojai neperka akcijų, kurios smarkiai atpigo rinkoje, dèl finansinių priežasčių, o perka tas kurios atpigo dèl kitų priežasčių, pavyzdžiui dèl žiniasklaidoje pasirodžiusio skandalo.

Kiti investuotojai renkasi augimo akcijas ir ieško įmonių, kurios pasižymi sparčia plètra, kurių kainos kyla ir yra tikimasi, kad tokia tendencija išliks ir toliau dèl pelno reinvestavimo. Taip pat šioms akcijoms būdinga, kad jos turi žemą balansinès ir rinkos vertès santykị. Fundamentalios analizès požiūriu yra skiriama daugiau dèmesio ateities perspektyvų vertinimui.

Šių investavimo strategijų vertinimui yra labai svarbus kainos ir pelno vienai akcijai santykis, kuris gaunamas dabartinę akcijos kainą padalinus iš gauto pelno vienai akcijai. Skirtingų požiūrių investuotojai atkreips dèmesị i kitus aspektus renkantis investiciją.

Reilly, Brown (2006) pažymi, kad investuotojai, kurie vadovaujasi akcijų augimo principu, rinksis akcijas, kurios atitinka šiuos bruožus:

- Skaičiuojant kainos ir pelno vienai akcijai santykị, dagiau dėmesio atkreipia ị pelno vienai akcijai komponentą.

- Ieško įmonių, iš kurių tikisi greito augimo pelno vienai akcijai.

- Tikimasi, kad artimiausiu metu akcijos kainos ir pelno vienai akcijai santykis išliks toks pats ir akcijos kaina išaugs kartu su pelnu vienai akcijai kaip prognozuota.

Vertès investuotojai atkreipia dèmesį:

- Skaičiuojant kainos ir pelno vienai akcijai santykị koncentruojasi ties kaina ir investuotojas turi būti užtikrintas, kad kaina rinkoje bus pigi, dèl tam tikrų priežasčių.

- Nekreipia dèmesio ị dabartinị pelną iš vienos akcijos arba ị tai kas skatina pelną vienai akcijai.

- Investuotojai žino, kad kainos ir pelno vienai akcijai santykis gali būti žemesnis negu jo normalus lygis ir tikisi, kad rinka ištaisys savo klaidą ir akcijos kaina pakils, o pelnas vienai akcijai išliks toks pats arba pakis labai nežymiai.

Lyginant šiuos du investavimo metodus autoriai pastebi, kad vertės strategija yra rizikingesnè ilgesniame laiko horizonte, negu augimo strategija. Taip pat vertès investavimo strategija neįvertina žmogiškujų išteklių, nes žmogiškieji ištekliai palaiko augimo strategiją (Cronqvist et al. 2015). Taip pat atlikti tyrimai rodo, kad investuotojai savo investavimo strategiją pasirenka pagal savo charakterị, bei patirtị. Investuotojai, kurie susidūrè su sudètingomis ekonominèmis sąlygomis ar išgyveno ekonominius sunkumus bus labiau linkę investuoti pagal vertės strategiją, negu augimo (Cronqvist et al. 2015).

Dividendinio pajamingumo strategija yra skirta investuotojams, kurie nori pastovių pajamų arba turi galimybę reinvestuoti dividendus ir ịsigyti kitų akcijų. Kadangi išmokèti dividendus gali tik ịmonès, kurios yra finansiškai stabilios ir subrendusios, todèl investuotojai ieško stiprių įmonių kuriomis turi galimybę laikui bėgant padidinti dividendus. Taip pat ši investavimo strategija yra pakankamai nerizikinga, todèl yra patartina investuoti asmenims, kurie yra vyresni, o ne jauniems žmonėms. Empiriniai tyrimai rodo, kad akcijos, kurios yra didesnio likvidumo yra 
labiau linkę išmokèti dividendus, negu akcijos, kurios nėra tokios likvidžios (Jiang et al. 2017). Taip pat tyrimai rodo, kad įmonès yra labiau linkusios išmokèti dividendus, tada kai yra meškų rinka, negu bulių. Taip yra dèl to, kad įmonès norèdamos pritraukti finansavimą žada išmokèti dividendus, kai yra rinkos nuosmukis ir investuotojų lūkesčiai suprastejja (Beladi et al. 2016).

\section{Išvados}

Rengiant straipsnį atlikta analizė leido padaryti šias išvadas ir apibendrinimus:

1. İvertinus literatūroje pateikiamus investavimo sąvokų apibrèžimus galima teigti, kad investavimas, tai mechanizmas, kurio yra atsisakoma dabartinio vartojimo perkant vertybinius popierius ar kitą turtą ir tikintis finansinès grąžos, socialinio rezultato arba kitos naudos ateityje.

2. Literatūroje yra sutinkama gana didele investavimo strategijų ịvairové, kurių dalis turi tiek pasyvaus, tiek aktyvaus, tiek prognozemis paremto, tiek prognozių neįvertinančio investicijų valdymo elementų, todẻl galimas tik santykinis strategijų priskyrimas atskiroms strategijų grupems.

3. Pasyvaus investavimo strategijos daugeliu atveju yra laikomos labai paprastomis ir tapatinamos su pirk ir laikyk strategija, kuomet investavus vieną kartą, investicijų sudetis nėra keičiama visą investavimo laikotarpi, tačiau analizè parodè, kad nemaža dalis pasyvaus investicijų valdymo strategijų reikalauja perbalansavimo, o dalis iš jų yra pakankamai sudėtingos, kuomet investuojant papildomai yra apsidraudžiama perkant išvestines finansines priemones.

4. Aktyvus investavimas dažniausiai yra siejamas su techninės analizės įrankių taikymu, tačiau ịvertinus tai, kad investavimo laiko horizontas gali būti pakankamai ilgas, net vykdant investicijų perskirstymą kas mènesị ar kas ketvirtį, toks investavimas gali būti priskirtas aktyviam investicijų valdymui, o priimant sprendimus gali būti vadovaujamasi arba integruojami fundamentaliosios analizès elementai.

5. Aktyviai investicijas valdantys investuotojai siekia uždirbti iš didelių kainų svyravimų, todėl tinkamos investuoti įmonès pasirinkimas jiems nèra kertinis. Tinkamos, perspektyvios įmonès pasirinkimas yra daug svarbesnis pasyvaus investavimo šalininkams, kurie priklausomai nuo savo poreikių ir požiūrių renkasi vieną iš trijų imonių tipų - vertès, augimo arba dividendinio pajamingumo.

\section{Literatūra}

Beladi, H.; Chao, C. C.; Hu, M. 2016. A macro-analysis of financial decisions: an examination of special dividend announcements, International Review of Financial Analysis (48): 162-181. https://doi.org/10.1016/j.irfa.2016.09.015

Bodie, Z.; Kane, A.; Marcus, A. J. 2013. Essentials of investments. Ninth ed. the Mc Graw-Hill Companies, Inc. 740 p.

Cronqvist, H.; Stephan, S.; Yu, H. 2015. Value versus growth investing: Why do different investors have different styles?, Journal of Financial Economics, 333-349. https://doi.org/10.1016/j.jfineco.2015.04.006

Černius, G. 2011. Namu ūkio finansu valdymas. Mykolo Romerio universitetas. 187 p.

Dichtl, H.; Drobetz, W.; Kryzanowski, L. 2016. Timing the stock market: Does it really make no sense?, Journal of Behavioral and Experimental Fiannace (10): 88-104.

Dierkes, M.; Erner, C.; Zeisberger, S. 2010. Investment horizon and the attractiveness of investment strategies: a behavioral approach, Journal of Banking \& Finance (34): 1032-1046. https://doi.org/10.1016/j.jbankfin.2009.11.003

Elton, E.; Gruber, F. 1995. Modern portfolio theory and investment analysis. London: Routledge. 156 p.

Greqam, B. P.; Thema, P. J. 2004. Portfolio Insurance Strategies:OBPI vesrus CPPI, 568-578.

Haan, L.; Kakes, J. 2011. Momentum or contrarian investment strategies: evidence from Dutch institutional investors, Journal of Banking \& Finance (35): 2245-2251. https://doi.org/10.1016/j.jbankfin.2011.01.027

Yaqiong, Y. 2012. Momentum, contrarian, and the January seasonality, Journal of Banking \& Finance (36): 2757-2769.

Jiang, F.; Ma, Y.; Shi, B. 2017. Stock liquidity and dividend payouts, Journal of Corporate Finance (42): $295-314$. https://doi.org/10.1016/j.jcorpfin.2016.12.005

Jurevičienè, D. 2008. Asmeniniu finansu pagrindai. Vilnius: Technika. 196 p. https://doi.org/10.3846/1021-S

Kancerevyčius, G. 2009. Finansai ir investicijos. Kaunas: Smaltijos leidykla. 880 p.

Kung, J. J.; Wu, E. 2013. An evaluation of some popular investment strategies under stochastic rate, Mathematics and Computers in Simulation (94): 96-108. https://doi.org/10.1016/j.matcom.2012.10.006

Lee, C. F.; Shih, W. K.; Chen, H. Y. 2011. Technical, fundamental, and combined information for separating winners from losers [interaktyvus], [žiūrèta $2016 \mathrm{~m}$. gruodžio 20 d.]. Prieiga per internetą:

http://papers.ssrn.com/sol3/papers.cfm?abstract_id=1590460

Lietuvos Respublikos Investiciju istatymas [interaktyvus], 1999 [žiūrèta $2016 \mathrm{~m}$. lapkričio $12 \mathrm{~d}$.] Prieiga per internetą: https://www.e-tar.lt/portal/lt/legalAct/TAR.C7E57DF3CEC5

Macijauskas, L. 2015. Finansu rinku dalyviu iracionalumu paremta taktiné turto alokacija: daktaro disertacija. Vilnius: Technika. $141 \mathrm{p}$.

Martinkutè-Kaulienè, R. 2006. The use of derivates for risk management in Lithuania, in $4^{\text {th }}$ International Scientific Conference Business and Management. $14^{\text {th }}$ International Scientific Conference Enterprise Management: Diagnosis, Strategy, Efficiency. Conference Proceedings. 5-6 October 2006, Vilnius: Technika, 2006, 1-4.

Mcallen, F. 2010. Common sense investing [interaktyvus], [žiūrèta $2016 \mathrm{~m}$. lapkričio $13 \mathrm{~d}$.] Prieiga per internetą: $\mathrm{http}: / / \mathrm{www}$. google.lt/books?hl=lt\&lr=\&id=4E00B9QGYLIC\&oi=fnd\&pg=PA6\&dq=Common+Sense+Investing\&ots= $3 \mathrm{hDregWtSY} \&$ sig $=\mathrm{kXf}-\mathrm{V}_{-}-$

cbHTiVQfTvuY5PW5s3J4\&redir_esc=y\#v=onepage \&q=Common\%20Sense\%20Investing \& $\mathrm{f}=$ false 
Reilly, F.; Brown, K. 2006. Investment analysis \& portfolio management. Thomson South Western, 1174 p.

Rutkauskas, A. V.; Martinkutė, R. 2000. Investavimo ị NT strategijos plètotė atsižvelgiant ị riziką, Verslas, vadyba ir studijos. Vilnius: Technika, 292-297.

Rutkauskas, A. V.; Miečinskienè, A.; Stasytytè, V. 2008. Investment decisions modelling along sustainable development concept on financial markets, Technological and Economic Development of Economy Baltic Journal on Sustainability, $417-427$.

Rutkauskas, A. V.; Stankevičius, P. 2006. Investiciniu sprendimu valdymas. Vilnius. 374 p.

Treigienè, D. 2010. Investicijos. Vilnius: Technika. 256 p. https://doi.org/10.3846/1134-S

Valakevičius, E. 2008. Investavimas finansu rinkose. Kaunas: Technologija. 339 p.

Wiedemer, D.; Wiedemer,R. A.; Spitzer, C. S. 2012. The aftershock investor. New Jersey: John Wiley \& Sons. Inc. Hoboken.

Zhang, T.; Zhou, H.; L,i L.; Gu, F. 2015. Optimal rebalance rules for the constant proportion portfolio insurance strategy Evidence from China, Economic Systems (39): 413-422. https://doi.org/10.1016/j.ecosys.2015.02.001

Zieling, D.; Mahayni, A.; Balder, S. 2014. Performance evaluation of optimized portfolio insurance, Journal of Banking \& Finance (43): 212-225. https://doi.org/10.1016/j.jbankfin.2014.03.027

\title{
ANALYSES OF SELECTION AND CLASSIFICATION OF INVESTMENT STRATEGIES IN STOCK MARKET
}

\section{Ieva GAIGALAITĖ, Grigorij ŽILINSKIJ}

\begin{abstract}
The article is dealt with the investment strategies of the stock market options, and strategies are classified, according to the investor behaviour in the market and how they actively participate and investment. An examination of the literature investment concepts and offered them summarizing the definition of investment, a brief presentation of the investment strategy concept distinguishes two key investment strategies of the group. Taking literature occurring in investment strategies diversity and briefly after a description of them, the strategy is a systemized based on the general terms of investor activity and offering active and passive investment strategies classification. Taking an active and a passive investment strategy features provided insight into the investment for the selection of active and passive investments managing investors, depending on the investor's attitude, expectations and activity.
\end{abstract}

Keywords: investment, investment management, investment portfolio, investment strategy, active investing, passive investing. 